\title{
Effect of nucleotide-containing feed on growth and biochemical parameters of juvenile Japanese sea cucumber, Apostichopus japonicus (selenka, I867) (Echinodermata: Holothuroidea)
}

\begin{abstract}
The effect of multicomponent feed formulae on body weight and survival rate of juvenile Japanese sea cucumber was studied at a hatchery farm. It has been found that the growth rate of juveniles exposed to a constant water temperature and salinity is high. DNA from salmon milt, included in the feed formula at a concentration of $1 \mathrm{mg} / \mathrm{kg}$, exhibits a stimulating effect on juveniles' growth parameters. A higher DNA content of feed $(5 \mathrm{mg} / \mathrm{kg})$ reduces its feed conversion ratio. Salmon milk DNA was manufactured by salt extraction and ethyl alcohol precipitation. The product is a fragment of nucleoproteins with a mass of about $300 \mathrm{kDa}$.

The seasonal water freshening causes the growth rate and the rate of feed consumption to decrease. The introduction of DNA in feed contributes to the accumulation of larger amounts of protein and hexosamines in tissues of juvenile sea cucumbers as compared to the control.
\end{abstract}

Keywords: Japanese sea cucumber, aquaculture, feed, DNA, oligonucleotides, growth rate
Volume 8 Issue 4 - 2019

\author{
Nikolay N Kovalev, Yuliya M Pozdnyakova, \\ Svetlana E Leskova, Roman V Esipenko, \\ Evgeniy $\bigvee$ Mikheev \\ Far Eastern State Technical Fisheries University, Russia
}

Correspondence: Nikolay N Kovalev, Far Eastern State Technical Fisheries University, Vladivostok, 690087, Russia, Email kovalevnn6I@yandex.ru

Received: August 13,2019 | Published: August 26, 2019

\section{Introduction}

The growing world-wide demand for Japanese sea cucumber has caused an increase in the harvesting pressure on its natural populations and, as a consequence, a significant overfishing. Due to the depletion of natural resources, as well as the high commercial value, there was an urgent necessity to implement aquaculture programs for holothurians. The successful incubation of juvenile Apostichopus japonicus (Selenka, 1867) in the 1980s facilitated the development of aquaculture of the species in Japan and China. The increase in species stocks due to the release of juveniles was a reasonable solution aimed at recovery of natural populations. ${ }^{1}$

The major issue of sea cucumber farming is the lack of feed and scientifically substantiated dietary patterns. At the same time, calculation of energy budget provides a basis for evaluating different approaches to the use of feed nutrients. To date, very few models are known to calculate the energy of feed proposed for echinoderms. ${ }^{2}$

Differences in feed formulae are usually associated with the species of algae used, the quality of protein, and biologically active components introduced. Micronutrients play the role of growth stimulators, or components that provide higher survival rate of juveniles under conditions of aquarium-based rearing and aquaculture. Nevertheless, information on nutritional demands and preferred rations of juvenile Japanese sea cucumber is extremely limited, which hinders the development of methods for hatchery cultivation.

The goal of the study was to assess the effect of feed formulae containing DNA extracted from salmon milt on the growth and chemical composition of juvenile sea cucumber.

\section{Materials and methods}

The object of the study was hatchery-reared juvenile Japanese sea cucumbers obtained at the experimental sea cucumber cultivation facility in Severnaya Cove (Slavyanka Bay, Primorsky Krai). The juvenile sea cucumbers were kept in tanks with running water at a stocking density of 0,3 individuals per 1 liter. The animals were fed twice a day at a rate of $100 \mathrm{mg}$ of feed per individual.

The composition of the feed formula included dried kelp, fish flour, soybean meal, crushed bivalve shells, and freeze-dried sea cucumber internals at a ratio of 4:2:1:3:0.05. Flour is obtained by direct drying of minced meat of Alaska Pollock, contains (in \%): protein 85-86, fat- 1,5-2,0 and ash content of 3.5-4.5. The feed formulae were supplemented with DNA as a biologically active component in the form of nucleoprotein complex from salmon milt at a concentration of $1 \mathrm{~g}$ (feed no. 1) and $5 \mathrm{~g}$ (feed no. 2) per $1 \mathrm{~kg}$ of feed weight. Dry animal feed is produced by sintering method. Sintering was performed at $100^{\circ} \mathrm{C}$ within 30 minutes. When sintering the powder particles of the prescription mixture stick together under the influence of temperature, the air goes out, the mixture shrinks and compacts.

The basic feed formula was the control. The biologically active additive was obtained by salt extraction and ethyl alcohol precipitation. The product is a fragment of nucleoproteins with a mass of about $300 \mathrm{kDa} .^{3}$

The experimental studies were conducted for 101 days, from June to September. Water temperature and salinity were measured three times a day using an electronic thermometer and salinometer. Feed efficiency was assessed by variations in the body weight of the juvenile sea cucumbers.

Experimental data were processed based on the following parameters: survival rate, specific growth rate, feed consumption rate, and efficiency of food conversion. The parameters were calculated as follows ${ }^{4}$

$$
\text { Survival rate }(\%)=100 \times\left(N_{2} / N_{1}\right)
$$


Growth rate $\left(\%\right.$ day $\left.{ }^{-1}\right)=100 \times\left(\ln W_{2}-\ln W_{1}\right) / T$

Feed consumption rate $\left(g^{-1} d a y^{-1}\right)=I /\left[T\left(W_{2}+W_{1}\right) / 2\right]$

Feed conversion efficiency $(\%)=100 \times\left(W_{2}-W_{1}\right) / I$

where $\mathrm{N}_{1}$ is the number of animals at the beginning of experiment, $\mathrm{N}_{2}$ is number of animals at the end of experiment, $\mathrm{W}_{1}$ and $\mathrm{W}_{2}$ are the initial and final values of sea cucumber weight in each of the experimental tanks, $\mathrm{T}$ is the experimental period, and $\mathrm{I}$ is the dry weight of feed supplied to the tank.

The chemical composition of the muscular sac of sea cucumbers was identified based on the quantitative content of water-soluble proteins and hexosamines in the sea cucumber muscular sac. Sample preparation for the determination of water-soluble protein was carried out by extraction of homogenized tissue in distilled water in a ratio of $1 \mathrm{mg} / \mathrm{ml}$ for $1 \mathrm{~h}$ at a temperature of $25^{\circ} \mathrm{C}$. The extract was filtered through a paper filter. Protein content was determined in the filtrate by the method of Lowry et al..$^{5}$ The content of hexosamines was determined spectrophotometrically. The method is based on the interaction of hexosamines with an alkaline solution of acetylacetone at a $\mathrm{pH}$ of 9.6-9.7 when heated, followed by treatment with Erlich reagent. The optical density of the red-colored solution is measured at $530 \mathrm{~nm}^{6}$

The efficiency of feed with the DNA content of $1 \mathrm{mg}$ (feed no. 1) and $5 \mathrm{mg}$ (feed no. 2) per $1 \mathrm{~kg}$ of feed weight was assessed in comparison with a feed without DNA (control). Each experimental group of juvenile sea cucumbers was kept separately in 100-lilter tanks. To estimate variations in the body weight of juveniles, control weighing was carried out monthly. The animals were taken out from the water, dried on filter paper, and weighed on an electronic scale to an accuracy of $0.01 \mathrm{~g}$. After the weight measurements, the juveniles were put back in the same tanks where they were kept for further experimental cultivation. Survival rate was estimated by the number of juveniles that survived in each experiment. The number of animals by the beginning of the experiment was 30 in each group.

\section{Results}

The quantitative data on body weight variations and number of live juvenile sea cucumbers are presented in Table 1.

Table I The effect of feed formula on the body weight of juvenile sea cucumbers

\begin{tabular}{llll}
\hline Date, parameter & Feed no. I & Feed no. 2 & Control \\
\hline June 9 & $\mathrm{n}=30$ & $\mathrm{n}=30$ & $\mathrm{n}=30$ \\
& $0.23 \pm 0.1$ & $0.38 \pm 0.25$ & $0.25 \pm 0.15$ \\
Weight, g & & & \\
July 9 & $\mathrm{n}=23$ & $\mathrm{n}=25$ & $\mathrm{n}=26$ \\
Weight, g & $0.94 \pm 0.18$ & $1.45 \pm 0.10$ & $1.32 \pm 0.20$ \\
August I2 & $\mathrm{n}=23$ & $\mathrm{n}=22$ & $\mathrm{n}=25$ \\
Weight, g & $3.5 \pm 0.38$ & $2.83 \pm 0.24$ & $2.72 \pm 0.17$ \\
September 20 & $\mathrm{n}=21$ & $\mathrm{n}=21$ & $\mathrm{n}=24$ \\
Weight, g & $2.22 \pm 0.48$ & $1.36 \pm 0.28$ & $2.04 \pm 0.17$ \\
\hline
\end{tabular}

The data in the table show that the use of experimental feed formulae contributed to the body weight increase in the experimental animals. However, the increment in animals' weight during the 101 days of the experiment had a non-linear pattern. Thus, within the first month of the experiment, the weight of juvenile sea cucumbers in the experimental groups 1 and 2 increased 4.1- and 3.8-fold, respectively; in the control group, 5.3-fold. From July to August, the growth rate of juveniles reduced and amounted to $1.38 \mathrm{~g}$ for the group 2 and $1.4 \mathrm{~g}$ for the control group, respectively. At the same time, the body weight of the experimental group 2 increased by $2.56 \mathrm{~g}$. It should be noted that for the two months of the experiment, the weight of the juvenile sea cucumbers increased 10.9-fold in the control group (2.47g), 15.2-fold in the experimental group $1(3.27 \mathrm{~g})$, and 2.0 -fold in group $2(2.43 \mathrm{~g})$. The data obtained indicate a dose-dependent effect of the introduction of DNA from salmon milt on the growth of body weight of juvenile sea cucumbers.

According to the results of the study conducted, a decrease in the sea cucumber body weight occurred in all the experimental groups by September. The least pronounced body weight decrease was recorded from the animals of the experimental groups.

The above-described experiments were set up under conditions of a constant water temperature of $18 \pm 1.0^{\circ} \mathrm{C}$ in tanks. However, the water salinity measurements conducted in the course of the experiment showed some seasonal fluctuations in this parameter (Figure 1).

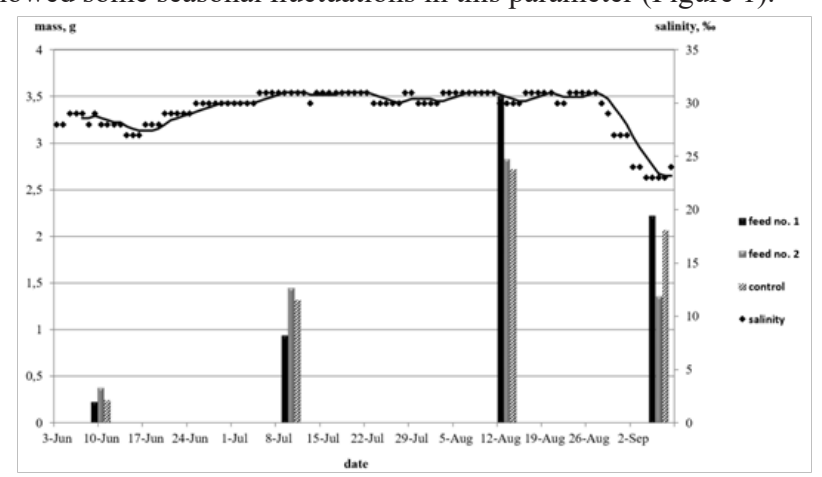

Figure I Dynamics of water salinity (\%०) and sea cucumber weight (g) values during the experiment.

According to the data presented in Figure 1, the salinity in June was 28-29\%; in July and August, 30-31\% ; and since the early September, it decreased to $23 \%$. It should be noted that the weight of the experimental animals reduced as the water salinity decreased. The reduction in the sea cucumber weight in September, compared to that in August, was by 36.6 and 51.9\% in the experimental groups 1 and 2 , respectively, and only by $25 \%$ in the control group. An analysis of the results of the experiment shows that the feed formulae tested had a varying effect on the weight of juvenile sea cucumbers.

The introduction of DNA in the feed formula at a dose of $1 \mathrm{~g}$ per $1 \mathrm{~kg}$ of feed contributed to an increase in juveniles' weight by $965 \%$; at the same time, providing the sea cucumbers with the feed containing DNA at $5 \mathrm{~g}$ per $1 \mathrm{~kg}$ of feed caused their weight to increase only by $358 \%$. The animals' weight increase in the case of the control feed formula was $816 \%$.

The estimation of feed efficiency values (Table 2) during the first two months of the experiment showed that the growth rate and the feed conversion efficiency for feed no. 1 are higher than those in the control group. At the same time, a comparison of the efficiency values between the feeds with different DNA contents showed as follows: 
despite the rate of consumption of feed no. 2 is slightly higher than that of feed no. 1 , the conversion efficiency of the former is lower, which resulted in a 1.5 -fold lower growth rate of juvenile sea cucumbers and their lower survival rate.

Table 2 Efficiency of feed for juvenile Japanese sea cucumber

\begin{tabular}{|c|c|c|c|}
\hline Date, parameter & Feed no. I & Feed no. 2 & Control \\
\hline \multicolumn{4}{|l|}{ June-August } \\
\hline Survival rate, $\%$ & 77 & 73 & 83 \\
\hline Growth rate (\%) & 2.38 & 1.65 & 2.15 \\
\hline $\begin{array}{l}\text { Feed consumption rate } \\
\left(\mathrm{g}^{-1} \text { day } \mathrm{y}^{-1}\right)\end{array}$ & 9.51 & 9.84 & 9.39 \\
\hline $\begin{array}{l}\text { Feed conversion efficiency } \\
\text { (\%) }\end{array}$ & 0.79 & 0.55 & 0.72 \\
\hline \multicolumn{4}{|l|}{ August and September } \\
\hline Survival rate, \% & 70 & 70 & 80 \\
\hline Growth rate (\%) & 1.5 & 0.89 & 1.49 \\
\hline $\begin{array}{l}\text { Feed consumption rate } \\
\left(g^{-1} \text { day } y^{-1}\right)\end{array}$ & 9.21 & 8.7 & 7.7 \\
\hline $\begin{array}{l}\text { Feed conversion efficiency } \\
(\%)\end{array}$ & 0.61 & 0.3 & 0.61 \\
\hline
\end{tabular}

The trend of variations in the feed efficiency parameters during the period of seasonal freshening (in August and September) indicates a significant reduction in the growth rate of juvenile sea cucumbers. According to the data in Table 2, the growth rate reduction in the control group of animals is related, to a greater extent, with the rate of feed consumption, whereas in the experimental groups the decrease in feed conversion efficiency is more noticeable. Growth of organisms is accompanied by changes in biochemical parameters of their tissues. Some of the biochemical parameters were determined during forming the stocking material and upon the completion of the experiment (Table 3).

Table 3 Level of hexosamines and water-soluble proteins in tissues of juvenile Japanese sea cucumbers

\begin{tabular}{llll}
\hline Specimen & Date & $\begin{array}{l}\text { Hexosamine } \\
\text { content, \% }\end{array}$ & $\begin{array}{l}\text { Water-soluble } \\
\text { protein content, } \\
\text { mg/g tissue }\end{array}$ \\
\hline initial & June & 0.1 & $9.8 \pm 0.1$ \\
No. I & & 1.2 & $13.7 \pm 0.1$ \\
No. 2 & September & 1.42 & $27.3 \pm 0.2$ \\
control & & 1.34 & $15.7 \pm 0.1$ \\
\hline
\end{tabular}

The data in Figure 2 show that all three types of experimental feeds caused a 1.4-2.8-fold increase in the level of water-soluble proteins in tissues of the juvenile sea cucumbers. In this case, the most pronounced effect of increase in water-soluble protein content was recorded for the feed with a high DNA content (no. 2). The difference in efficiency between the feeds with different DNA levels was 2-fold for this parameter. At the same time, the efficiency of the feed with a DNA content of $5 \mathrm{~g} / \mathrm{kg}$ was by $70 \%$ higher than that of the control feed. Hexosamines are monomers of glycosaminoglycans which are the main component of the extracellular matrix contributing to the formation of the dense structure of muscular sac in sea cucumbers.

Feeding the juvenile sea cucumbers with the control feed resulted in a 13.4-fold increase in hexosamine content. The experimental formulae with DNA increased the level of hexosamines 12-14 times. Apparently, the use of DNA in feed formulae stimulates the growth of muscle tissue and, as a consequence, the biosynthesis of proteoglycans containing hexosamines.

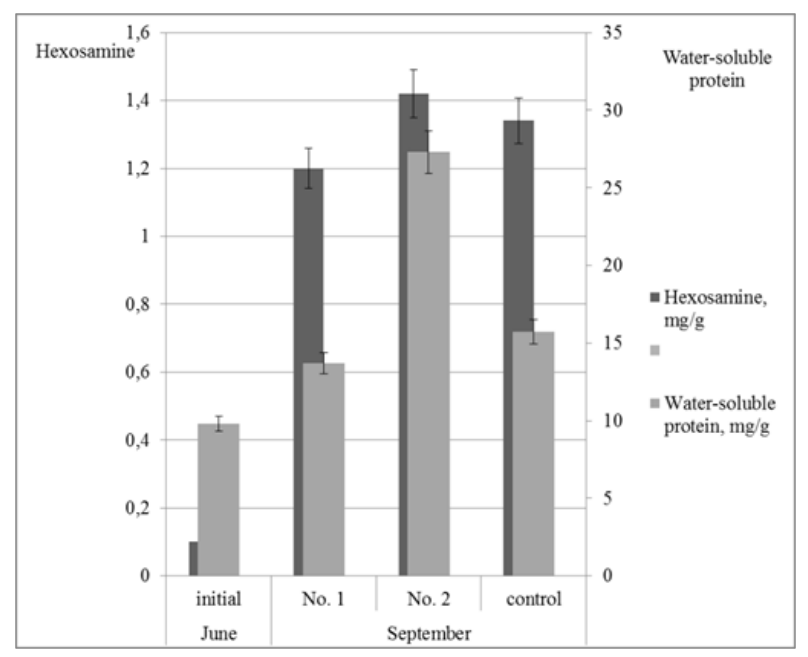

Figure 2 Level of hexosamines and water-soluble proteins in tissues of juvenile Japanese sea cucumbers.

\section{Discussion}

The intensive development of aquaculture necessitates searching for new efficient components and inventing feed formulae that would ensure production of viable juveniles. Nucleotides perform numerous physiological and biochemical functions such as transfer of chemical energy, participate in biosynthesis, biological regulation, and are coenzymes. $^{?}$

Numerous studies on different species of aquatic organisms confirm that the introduction of nucleotides in feed increases the growth rate in some fish species. ${ }^{8,9}$

It was shown that the inclusion of nucleotides has a dose-dependent effect for each fish species: $0.5 \mathrm{~g} / \mathrm{kg}$ of feed for common carp $^{10} 1.5 \mathrm{~g} / \mathrm{kg}$ for grouper ${ }^{11}$ and $2 \mathrm{~g} / \mathrm{kg}$ for rainbow trout. ${ }^{12}$

According to the conducted studies, the introduction of salmon DNA in feed for juvenile sea cucumber $(0.23-0.28 \mathrm{~g})$ in an amount of $1 \mathrm{~g}$ per $1 \mathrm{~kg}$ of feed contributes to an increase in animals' weight to a value by $28.7 \%$ higher than in the control within the first two months of use. Nevertheless, the feed supplemented with DNA did not influence the survival rate of the juvenile sea cucumbers in the experimental groups, which may also be associated with the negative effect of water freshening. However, the use of DNA-containing feed during this period helps to maintain the rate of consumption of feed and its conversion efficiency. 
At the same time, the introduction DNA into the feed in an amount of $5 \mathrm{~g}$ per $1 \mathrm{~kg}$ did not affect on young sea cucumber weight. Feeding sea cucumber with the addition of salmon milk DNA for 3 months did not affect the weight of juveniles sea cucumber $(1 \mathrm{mg} / \mathrm{kg})$, or contributed to weight loss $(5 \mathrm{mg} / \mathrm{kg})$.

The data obtained are consistent with the study of Wei with coauthors (2015) which showed that inclusion of nucleotides in feed formulae for Japanese sea cucumber (with the initial weight of $5.87 \pm 0.03 \mathrm{~g}$ ) showed that the specific growth rate was significantly higher in animals that consumed feed with a nucleotide content of $375 \mathrm{mg} / \mathrm{kg}$, as compared to those fed a feed without nucleotides added. In conclusion, it was shown that nucleotides, as a dietary component, actually increase growth rate, nonspecific immunity, and resistance to diseases in Japanese sea cucumber. ${ }^{13}$

The data obtained indicate the dose-dependent effect of introduction of DNA from salmon milt on the weight increase in juvenile sea cucumber.

In addition, juvenile sea cucumbers are sensitive to water salinity variations due to the high permeability of their external teguments. Our findings are consistent with the earlier studies, according to which the unusual size-frequency distribution of echinoderms in waters with significant salinity fluctuations is probably explained by the lower tolerance of small individuals to hypoosmotic stress. ${ }^{14,15}$

The use of DNA from salmon milk in feed formulae in the amount of $1 \mathrm{mg} / \mathrm{kg}$, apparently stimulates the growth of muscle tissues and, as a consequence, the biosynthesis of proteoglycans containing hexosamines. Thus, the study conducted by us shows that the inclusion of nucleotides from fish milt in feed formula is promising for on-growing of juvenile Japanese sea cucumbers. The use of DNA extracted from salmon milt may provide a new strategy for controlling health of sea cucumber in aquaculture.

\section{Acknowledgements}

None.

\section{Conflicts of interest}

The author declares that there are no conflicts of interest.

\section{Funding}

None.

\section{References}

1. YSFRI (Yellow Sea Fisheries Research Institute). Training manual on breeding and culture of scallop and sea cucumber in China. Yellow Sea Fisheries Research Institute, Manual 9 of Regional Sea farming Development and Demonstration Project. Qingdao, China. 1991;47-79.
2. Otero-Villanueva MM, Kelly MS, Burnell G. How diets influence energy partitioning in the regular echinoid Psammechinus miliaris; constructing an energy budget. The Journal of Experimental Marine Biology and Ecology.2004;304(2):159-181.

3. Kasyanenko, Yu I, Pivnenko TN. Comparative physical and chemical characteristics of low-molecular-weight deoxyribonucleic acid (DNA) from marine organisms. Izvestiya TINRO.1999;125:152-158.

4. Liu Y, Dong S, Tian X, et al. Effects of dietary sea mud and yellow soil on growth and energy budget of the sea cucumber Apostichopus japonicus (Selenka). Aquaculture. 2009;286(3);266-270

5. Lowry O, Rosenbrough N, Farr A, et al. Protein measurement with the Folin phenol reagent. The Journal of Biological Chemistry. 1951;193:266-275.

6. Jang $\mathrm{JH}$, Hia $\mathrm{HC}$, Ike $\mathrm{M}$, et al. Acid hydrolysis and quantitative determination of total hexosamines of an exopolysaccharide produced by Citobacter sp. Biotechnology Letter. 2005;27(1):13-18.

7. Li P, Gatlin DM. Dietary supplementation of a purified nucleotide mixture transiently enhanced growth and feed utilization of juvenile red drum, Sciaenops ocellatus. Journal of the world Aquaculture Society. 2007;38(2):281-286.

8. Abtahi B, Yousefi M, Kenari AA. Influence of dietary nucleotides supplementation on growth, body composition and fatty acid profile of Beluga sturgeon juveniles (Huso huso). Aquaculture Research. 2013;44(2), 254-260.

9. Kenari A, Mahmoudi AN, Soltani M, et al. Dietary nucleotide supplements influence the growth, haemato-immunological parameters and stress responses in endangered Caspian brown trout (Salmo trutta caspius Kessler 1877). Aquaculture Nutrition. 2012;19(1):54-63.

10. Xiang X, Zhou X, Chen J, et al. Effects of yeast nucleotide on growth performance, body composition and immune indices of common carp (Cyprinus carpio). Chinese Journal of Animal Nutrition. 2011;23:171178.

11. Lin YH, Wang H, Shiau SY, et al. Dietary nucleotide supplementation enhances growth and immune responses of grouper, Epinephelus malabaricus. Aquaculture nutrition. 2009;15(2):117-122.

12. Tahmasebi-Kohyani A, Keyvanshokooh S, Nematollahi A, et al. Dietary administration of nucleotides to enhance growth, humoral immune responses, and disease resistance of the rainbow trout (Oncorhynchus mykiss) fingerlings. Fish \& shellfish Immunology. 2011;30(1):189-193.

13. Wei Z, Yi L, Xu W, et al. Effects of dietary nucleotides on growth, non-specific immune response and disease resistance of sea cucumber Apostichopus japonicas. Fish \& Shellfish Immunology. 2015;47(1):1-6.

14. Xi X, Zhao W, Yang M. Combined influence of water temperature, salinity and body size on energy budget in the sea cucumber Apostichopus japonicus Selenka. Fisheries Science. 2013;79(4):639-646.

15. Romanenko EG, Klenina IA. A method to determine hexosamines in saliva. Vestnik Problem Biologii i Meditsiny. 2013;2(99):215-217. 